\title{
THE INFLUENCE OF TRANSIT TOURISTS TOWARDS THE DEVELOPMENT OF HOSPITALITY IN THE SOUTHEASTERN REGION
}

DOI: http://dx.doi.org/10.18509/GBP.2015.56

UDC: 338.488.2/640.4]/338.48-2-054.64(497.7-12),2009/2014““

\author{
M.Sc. Cvetanka Ristova ${ }^{1}$ \\ Ass. Prof. Ph.D. Tanja Angelkova Petkova ${ }^{1}$ \\ Goce Delcev" University - Stip, Faculty of tourism and business logistics - Gevgelija, \\ Republic of Macedonia
}

\begin{abstract}
The paper makes an attempt for acquaint with the importance of the tourist need and wishes of transit tourists and their contribution for the development of hotel industry, with purpose to foresee this potential as a gain for developing the southeastern region. In that direction, first is analyzed the southeastern region with its current condition of hotel accommodation. Next follows, analysis of transit tourists, according to the number of age and country of residence, and the immediate influence of the highway "Alexander the Great", which is part of the international route E-75. The influence of transit tourists towards the development of the hospitality is accomplished by analysis of the performance of consumption and discussion for forming an appropriate hotel product for transit tourists.
\end{abstract}

KEYWORDS: transit tourism, hotel industry, hotel product, southeastern region.

\section{INTRODUCTION}

Hospitality is one of the principal sectors in the tourism industry in the Republic of Macedonia, which is one of the most rapidly expanding fields in the service industry. The hotel industry has contributed to the enormous growth of the economy in the country by offering services for accommodation and food. Thus, it is important to show that the hotel offer is made exactly from the potentials of the certain area for developing selective types of tourism. Therefore, the Southeastern region is an area emerged as a hallmark of geologic diversity as tradition who is nurtured for ages. The mountains and hills on one hand, waterfalls, lakes and rivers and large number of cultural events distinguish the region from the others. But, for realizing a tourist income in the hotel industry, it is necessary to develop a hotel product convenient to the surroundings of the region and promote the same. Still, one of the main problems that hospitality has on a national level is the development design of the hotel itself. The Southeastern region's characteristics do not adapted to the hotel product and that it why there is a notable stagnation in the tourist arrival. This paper raises the question can the Southeastern region develop the hospitality by increasing the tourist arrivals with analyzing the given data from the State Statistical Office of the region's performance and direct it to a specific type of tourists, while forming an adequate hotel product. 


\section{ANALYSING THE POTENTIALS AND NEW FORMS OF TOURISM IN THE SOUTHEASTERN REGION}

The Southeastern region is one of eight regions of the Republic of Macedonia. Located in the southeastern part of the country, contains a total area of $2835 \mathrm{~km}^{2}$ and its borders with Greece to the south side, as well as Bulgaria, and to the north and west with Eastern region and Vardar region. The current population, according to the last population census in 2002 is 171,416 citizens. Southeastern region is divided into 10 municipalities: Bogdanci, Bosilovo, Dojran, Gevgelija, Konce, Novo Selo, Radovis, Strumica, Valandovo and Vasilevo.

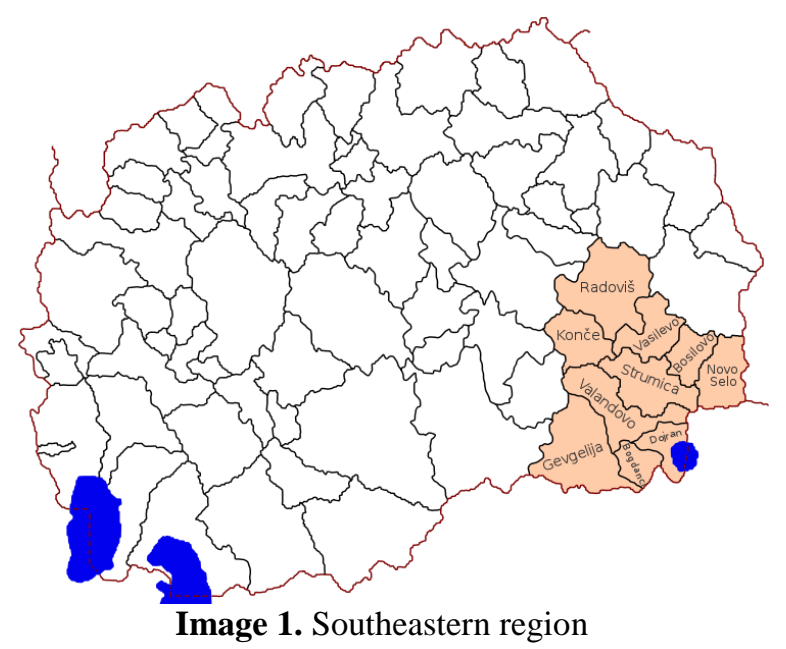

Due to its significant location in the country, the Southeastern region does not go unnoticed by tourists. Tourism statistics in this region show that the tourist arrivals noted variability through the years, but still ranking him as third most visited regions. From 2010 until 2013, the tourist arrival in the Southeastern region noticed a small difference between the domestic and foreign, where in 2013, 59.977 tourist arrivals are domestic and 50.005 tourist arrivals are foreign. Even though, the tourism statistics have a tendency of variability, the average number of nights spent is higher in this region by 2.81 days $^{[48]}$. Highlighting the location and connecting with the road traffic and border crossings as well as the characteristics of the Southeastern region, tourism and hospitality in general can benefit from the non-accommodation consumption by transit tourists.

Defining the resources of this region for attracting transit tourists, as a primary object of developing the Southeastern region, in Republic of Macedonia the transit tourists are defined as persons who enter this country from one borderline and exit from another, with the purpose of extending and completing their travel in another country without spending the night in the country ${ }^{[49]}$. Nevertheless, the needs of the transit tourists are fond of vacation and leisure which often covers service for accommodation for one night, because of the long travel period. At the same time, this non-accommodation consumption additionally benefits the development of the hospitality and increasing the tourist income in the country. For this reason, is analyzed the accommodation statistics in the

${ }^{[48]}$ Republic of Macedonia State Statistical Office. Tourism in the Republic of Macedonia 2009 2013, pp 44-46, 2014

${ }^{[49]}$ Republic of Macedonia State Statistical Office. Survey on foreign visitors at border crossings pp 6, 2009 
Southeastern region, establishing this offer as a necessary tool for satisfying the basic and most important needs of transit tourists.

Table 2. Accommodation capacities in the Southeastern region (2009 - 2013)

\begin{tabular}{|c|c|c|c|c|}
\hline Number of rooms & $\mathbf{2 0 1 1}$ & $\mathbf{2 0 1 2}$ & $\mathbf{2 0 1 3}$ \\
\hline $\mathbf{2 0 0 9}$ & $\mathbf{2 0 1 0}$ & 2.277 & 2.298 & 2.346 \\
\hline 2.152 & 2.105 & $\mathbf{2 0 1 1}$ & $\mathbf{2 0 1 2}$ & $\mathbf{2 0 1 3}$ \\
\hline Number of beds & $\mathbf{2 0 1 0}$ & 6.069 & 6.088 & 6.298 \\
\hline 5.750 & 5.724 &
\end{tabular}

Source: State Statistical Office.Tourism in the Republic of Macedonia 2009 - 2013, pp. 49

From Table 2, accommodation capacities in the Southeastern region are in constant elation. Even so, in period five years, the number of rooms is higher by $8.2 \%$, making this area unequal of the position of tourist arrivals. Regarding the number of rooms, the Southeastern region is on the fourth place by number of rooms, behind Southwestern, Pelagonia and Skopje region, as for a number of begs, the Southeastern region has more begs than the Skopje region, ranking him in third place ${ }^{[50]}$.

Table 3. Accommodation statistics in the municipalities

\begin{tabular}{|l|c|}
\hline Minicipality & Number of accommodation facilities \\
\hline Gevgelija & 11 \\
\hline Valandovo & 2 \\
\hline Dojran & 5 \\
\hline Strumica & 13 \\
\hline Vasilevo & 1 \\
\hline Radovis & 2 \\
\hline TOTAL & $\mathbf{3 4}$ \\
\hline \multicolumn{2}{|c|}{ Source: Authors own calculation } \\
\hline
\end{tabular}

According to the presented statistics this region disposes of various types of accommodation who are located here, that can take part in the tourist market for attracting transit tourists with suitable tourist offers and hotel product. The main accommodation facilities are located in Gevgelija, Dojran and Strumica, while in Dojran and Radovis are located only by 2 hotels and municipality Vasilevo only 1 motel. In the nearest municipalities to the border crossing Novo Selo like Novo Selo and Bosilovo, don't located any type of accommodation for tourists. This means that if the Southeastern region is established as transit region, certain management activities in hospitality are inevitable, such as developing a hotel design suitable for transit tourists. Among that is necessary to identify the influences that connect with the transit role in the region. This means, the role of the highway "Alexander the Great" and border crossings can be eminent for this region, meaning its accessibility from one road or more and accessing the hotel.

${ }^{50}$ Republic of Macedonia State Statistical Office. Tourism in the Republic of Macedonia 2009 2013, pp 49, 2014 


\section{THE ROLE OF BORDER CROSSINGS FOR}

\section{THE DEVELOPMENT OF TRANSIT TOURISM}

Determining the location of the accommodation facilities in the transit tourism has significance for its successful working in the hotel industry. Since road substructure is crucial for the development of accommodation offer to transit tourists, the role of the border crossing will allow the municipalities to attract the transit tourists and benefit from their consumption. Given to the fact, that the statistics data of the Republic of Macedonia is limited and does not offer any recent information about keeping data of tourists transiting through this country which will allow us to make segmentation, orientation and position the tourist offer for transit tourists, data has been used from the published statistics of State Statistical Office: Transport and other services from 2010, 2012 and 2013 which will give a number of registered passengers of the border crossings and yearly they use the territory of the Republic of Macedonia for transit or visit.

Table 4. Passenger traffic at border crossings

\begin{tabular}{|c|c|c|c|c|c|}
\cline { 3 - 6 } \multicolumn{2}{c|}{} & \multicolumn{2}{c|}{ Domestic } & \multicolumn{2}{c|}{ Foreign } \\
\hline & Year & Entrance & Exit & Entrance & Exit \\
\hline Bogorodica & $2009^{[1]}$ & 355.443 & 393.761 & 1.146 .781 & 1.027 .828 \\
\hline & 2010 & 468.418 & 526.817 & 1.342 .297 & 1.140 .503 \\
\hline & 2011 & 544.997 & 624.104 & 1.554 .541 & 1.318 .344 \\
\hline & 2012 & 506.155 & 630.517 & 1.371 .349 & 1.173 .091 \\
\hline \hline & 2013 & 453.655 & 570.871 & 1.278 .626 & 1.044 .152 \\
\hline Novo Selo & $2009^{[1]}$ & 73.352 & 71.395 & 108.276 & 104.331 \\
\hline & 2010 & 108.579 & 112.000 & 120.057 & 117.882 \\
\hline & 2011 & 120.971 & 125.223 & 157.530 & 157.832 \\
\hline & 2012 & 126.086 & 130.194 & 178.161 & 177.700 \\
\hline & 2013 & 141.125 & 146.241 & 185.040 & 182.659 \\
\hline & \multicolumn{5}{r}{ Source: State Statistical Office. Transport and other services, various publications } \\
\end{tabular}

From Table 4, one of the most frequent border crossing in Republic of Macedonia is Bogorodica, although in 2013 is noted decreasing both from domestic and foreign passengers, still international highway E-75 with a length of $174 \mathrm{~km}$, crosses right through the border crossing Bogorodica, connects him with Finland, Poland, Czech Republic, Slovania, Hungary, Serbia and Greece. It is important to know that the international highway E-75 named "Alexander the Great" in the Republic of Macedonia from ancient times until now, provides for the tourists a shorter time of travelling, and therefore his advantage comes from this. The border crossing Novo Selo detects almost the same number of domestic and foreign passengers with consistent growth. Regardless of, the construction of hotels with the proper development design in this area will attract transit tourists and developed the hotel industry as well as the income from it.

\section{RESEARCH, ANALYSIS AND DISCUSION}

With the purpose of determining the needs of transit tourists and increase their nonaccommodation consumption at the hospitality in the Southeastern region, a questionnaire was realized at the border crossing Bogorodica in three time periods:

- June - August 2013,

- November - December 2014,

- March - April 2014. 
The questionnaire contained 8 questions and the same was anonymous and in writing. It is necessary to mention that the language barrier was a problem with some respondents.

Table 5. Arrivals of transit tourists by country of origin

\begin{tabular}{|l|c|c|c|}
\hline State & June - August 2013 & November - December 2014 & March - April 2014 \\
\hline Germany & 4 & & \\
\hline Greece & 5 & 5 & 3 \\
\hline Poland & 2 & & \\
\hline Russia & 1 & & 2 \\
\hline Serbia & 18 & & 1 \\
\hline Turkey & 2 & & \\
\hline Netherlands & 4 & & \\
\hline
\end{tabular}

From the transit tourists that cross along the Republic of Macedonia's region through the whole year are the transit tourists from Greece, from June to August (5 transit tourists), November to December (5 transit tourists) and March to April (3 transit tourists). From the Balkan countries, most of the respondents are from Serbia, from June to August (18 transit tourists) and March to April (2 transit tourists). Other countries that also travelled across the Republic of Macedonia are Germany in June to August (4 transit tourists), Poland in June to August (2 transit tourists), Russia in June to August (1 transit tourist), Turkey, from June to August (2 transit tourists) and from March to April (1 transit tourist), and the Netherlands in June to August (4 transit tourists).

Table 6. Arrivals of transit tourists according to their age

\begin{tabular}{|l|c|c|c|}
\hline Age & June - August 2013 & November - December 2014 & March - April 2014 \\
\hline $15-19$ & & & 3 \\
\hline $20-29$ & 7 & 2 & 3 \\
\hline $30-39$ & 13 & 2 & \\
\hline $40-49$ & 11 & & \\
\hline $50-59$ & 3 & & \\
\hline $60-69$ & & & \\
\hline $70+$ & 3 & & \\
\hline
\end{tabular}

From the analyzed statistics, the age of transit tourists that crosses through the Republic of Macedonia are from 30 to 39, where 13 transit tourists travelled from June to August, 2 from November to December and 3 from March to April. Others are from 40 to 49, where 11 tourists travelled from June to August and 2 from November to December, as well as tourists from 20 to 29, where 7 travelled from June to August, 1 from November to December and 3 from March to April. Notable is the transit of tourists from the age of 50 to 59 where 2 tourists travelled from June to August and tourists from 60 to 69 in the same period.

Table 7. Analysis of the needs of transit tourists for the time they spent travelling

\begin{tabular}{|l|c|c|c|}
\hline Service / Product & June - August 2013 & November - December 2014 & March - April 2014 \\
\hline Food and beverage & 27 & 5 & 6 \\
\hline $\begin{array}{l}\text { Facilities for maintain } \\
\text { personal hygiene, toilet }\end{array}$ & 35 & 5 & 3 \\
\hline $\begin{array}{l}\text { Internet access and } \\
\text { telephone services }\end{array}$ & 22 & 2 & 3 \\
\hline First aid & 17 & 3 & 4 \\
\hline $\begin{array}{l}\text { Newspapers, books and } \\
\text { souvenirs }\end{array}$ & 15 & 1 & 1 \\
\hline
\end{tabular}




\begin{tabular}{|l|l|l|l|}
\hline Touristic information & 23 & 2 & 2 \\
\hline Road services & 31 & 2 & 2 \\
\hline $\begin{array}{l}\text { Information about the } \\
\text { condition of the roads }\end{array}$ & 31 & 5 & 6 \\
\hline
\end{tabular}

Summarizing the data from the research, for the transit tourists one of the most important services while travelling are the facilities for personal hygiene (total 43 responders), the road services (total 35 responders) and information for the condition of the roads (total 42 responders). Others are food and beverage (total 38 responders), tourist information (total 27 responders), Internet and telephone services (total 27 responders), first aid (total 24 responders) and the product that transit tourist need less are the newspapers, books and souvenirs (total 17 responders). The respondents to this question had a multiply choice for answers.

Table 8. Arrivals of the transit tourists according the chosen facility of accommodation

\begin{tabular}{|l|c|c|c|}
\hline $\begin{array}{l}\text { Type of accommodation } \\
\text { facilities }\end{array}$ & $\begin{array}{c}\text { June - August } \\
2013\end{array}$ & $\begin{array}{c}\text { November - December } \\
2014\end{array}$ & $\begin{array}{c}\text { March - April } \\
2014\end{array}$ \\
\hline Hotel & 10 & & \\
\hline Motel & 2 & & \\
\hline Hostel & & & \\
\hline Night quarter & & & 6 \\
\hline Other & 24 & 5 & 6 \\
\hline $\begin{array}{l}\text { I didn't use service for } \\
\text { accomodation }\end{array}$ & & & \\
\hline
\end{tabular}

During their visit in the Republic of Macedonia, transit tourists answered that they didn't use a service for accommodation where 24 transit tourists responded from June to August, 5 transit tourists from November to December and 6 transit tourists from March to April. The only noticed accommodation during the period from June to August where 10 transit tourists used services in a hotel and 2 transit tourists used services in a motel.

On the question of How many nights have the transit tourists spent in the chosen object of accommodation?, given the fact that only 12 transit tourist used this service from the period of June to August, the answer is 1 night. Also, on the question, What kind of service they often choice in the chosen object of accommodation? the 12 transit tourists answered bed and breakfast (BB).

Table 9. Analyzed the spending of transit tourists

\begin{tabular}{|l|c|c|c|}
\hline Amount & June - August 2013 & November - December 2014 & March - April 2014 \\
\hline $5-10$ euro & 7 & & 1 \\
\hline $10-20$ euro & 5 & 2 & 3 \\
\hline $20-40$ euro & 4 & 1 & 1 \\
\hline $40-50$ euro & 6 & 1 & 1 \\
\hline $50-100$ euro & 8 & 1 & \\
\hline $100+$ euro & 6 & & \\
\hline
\end{tabular}

The average amount that transit tourists spent on their travelling across the Republic of Macedonia, by the total summarizing is from 40 to 100 euro where 10 transit tourists equal in both section have spent this amount. Next, 8 transit tourists have spent over 100 euro, 7 transit tourists have spent from 5 to 10 euro, 6 transit tourists have spent from 10 to 40 euro equal by section. 
For the realized research at the border crossing Bogorodica, the purpose of analyzing the transit tourists and forming an adequate hotel offer, has given us the data that most of the transit tourists travel across the region of the Republic of Macedonia, right through the Southeastern region in the summer. With higher frequency, the visit of numerous transit tourists from different region of origin is noticed as well as age. Analyzing their need for accommodation and certain service of product, is leading to forming a proper hotel product, which can be promoted to the transit tourists that stated that besides their needs of services and product, didn't use a service of accommodation. Since their service at the accommodation facilities is bed and breakfast (BB), given the know information that usually the arrival of transit tourists is in the afternoons, and the departure at the mornings, a collaboration with the travel agencies can be arranged of organizing programs suitable for the hotel product that might include manifestation in the evening or visits early at the morning, even so, this offer can be made for the transit tourists that often use a car as transportation. Surely, unavoidably is to mention that every program that will the hotel product include should be segmented, since often visits include young people, couples, bus tours, families and others.

\section{CONCLUSION}

Transit tourists as a potential market for the development of hospitality in the Southeastern region have been only a saying. With the proper research this region has the potentials of making transit tourism one its primary resource for the hotel industry. As we've fortified transit tourists because of the long term period of traveling often use a service of accommodation. Their needs can be divided into basic and additional, whereas the research show all of the needs of accommodation and food, road services and information, Internet, facilities for personal hygiene can be classified as basic, while every other need of discovering and explore a new country can be classified as additional. Therefore, one of the main characteristics of the transit tourists is the non-accommodation consumption, which is representing a basic for the development of the tourism and hospitality itself. This means, that with the development of a proper hotel design or construction of new hotels close to main roads, this region regarding the closeness of the highway "Alexander the Great" and the two border crossings Bogorodica and Novo Selo, along with the unique characteristics of the Southeastern region, transit tourists can effect of the hotel industry, and benefit in the gross domestic product of the Republic of Macedonia. 


\section{REFERENCES}

[1] Republic of Macedonia State Statistical Office. Tourism in the Republic of Macedonia 2009 - 2013, pp 44-46, 2014

[2] Republic of Macedonia State Statistical Office. Survey on foreign visitors at border crossings pp 6, 2009

[3] Republic of Macedonia State Statistical Office. Tourism in the Republic of Macedonia 2009 - 2013, pp 49, 2014

[4] Republic of Macedonia State Statistical Office. Transport and other services 2013, pp 79,2014

[5] Republic of Macedonia State Statistical Office. Transport and other services 2012, pp 79,2013

[6] Republic of Macedonia State Statistical Office. Transport and other services 2010, pp 58,2011

[7] The Centre for development of the South-East region. Plan for the development of Southeastern mountain region, pp 13, 2008

[8] The Centre for development of the South-East region. Timeless brochure, pp 16, pp 24,2008

[9] Petrov, K., Poposka M., Trpcevski, F., Basics of hospitality and tourism, pp 65, 1992 